\title{
Intervensi Mindful Breathing Untuk Mengatasi Stres Akademik pada Remaja Sekolah Menengah Atas
}

\author{
Primalita Putri Distina \\ Islamic Psychology Major of IAIN Syaikh Abdurrahman Siddik Bangka Belitung, Indonesia \\ ppdistina@gmail.com
}

\begin{abstract}
High school students are prone in experiencing academic stress. Academic stressors faced are in the form of pressure to have a lot of assignments, length of study, poor time management, to anxiety facing exams. Some research shows that academic stress of high school students are in the high category. In an extreme case, academic stress can lead to self-harm behavior. One of the interventions that can overcome academic stress is mindful breathing. This study aims to determine the result of mindful breathing intervention to overcome academic stress in high school students. This study used a single-subject design, with one subject aged 16 years who was in grade XI. The flow of intervention consists of counseling sessions, preparation, implementation of the intervention, and evaluation. The results showed that the mindful breathing intervention was successful in dealing with academic stress in high school students.
\end{abstract}

Keywords: Mindful Breathing, Mindfulness, Academic Stress, Student, High School

Abstrak: Siswa SMA rentan mengalami stres akademik. Stressor akademik yang dihadapi berupa tekanan untuk naik kelas, tugas yang banyak, lamanya belajar, manajemen waktu yang buruk, hingga kecemasan menghadapi ujian. Beberapa hasil penelitian menunjukkan, siswa SMA mengalami stres akademik yang berada pada kategori tinggi. Pada beberapa kasus ekstrim, stres akademik dapat memicu perilaku self-harm. Salah satu intervensi yang dapat mengatasi stres akademik adalah mindful breathing. Penelitian ini bertujuan untuk melihat keberhasilan intervensi mindful breathing untuk mengatasi stres akademik pada siswa SMA. Penelitian ini menggunakan desain single-subject, dengan satu subjek berusia 16 tahun yang berada di kelas XI SMA. Alur intervensi terdiri dari sesi konseling, persiapan, pelaksanaan intervensi, dan evaluasi. Hasil penelitian menunjukkan bahwa intervensi mindful breathing berhasil mengatasi stres akademik pada siswa SMA.

Kata kunci: Mindful Breathing, Mindfulness, Stres Akademik, sSswa, Sekolah Menengah Atas 


\section{Pendahuluan}

Indonesia telah mencanangkan wajib belajar 12 tahun bagi seluruh warganya. Tujuan pendidikan nasional, seperti yang tertuang dalam UndangUndang Nomor 20 tahun 2003 tentang Sistem Pendidikan Nasional Pasal 3, adalah mengembangkan potensi peserta didik agar menjadi manusia yang beriman dan bertakwa kepada Tuhan Yang Maha Esa, berakhlak mulia, sehat, berilmu, cakap, kreatif, mandiri, dan menjadi warga negara yang demokratis. Pendidikan secara formal diberikan di sekolah dalam bentuk kegiatan belajar mengajar di dalam kelas. Akan tetapi, tidak selamanya proses belajar ini dapat berjalan dengan baik.

Siswa yang menjadi pelaku aktif dalam menerima pendidikan di sekolah, dituntut untuk mampu mengikuti seluruh kegiatan yang ada di sekolah. Siswa yang tidak mampu menyesuaikan diri terhadap beban dan tuntutan akademik, serta kurikulum yang padat cenderung rentan mengalami stres. Stres menjadi bagian dari kehidupan akademik siswa yang disebabkan oleh berbagai ekspektasi internal dan eksternal yang diberikan kepada mereka (Reddy, Menon, \& Thattil, 2018). Kondisi seseorang yang mengalami tekanan sebagai hasil dari persepsi dan penilaiannya terhadap stressor akademik umumnya disebut sebagai stres akademik (Govaerst \& Gregoire, 2004).

Stressor akademik berasal dari kegiatan belajar mengajar, seperti adanya tekanan untuk naik kelas, banyaknya tugas, waktu atau lamanya belajar, manajemen waktu yang buruk, dan kecemasan menghadapi ujian. Selain itu, jarak lokasi sekolah, kondisi kelas, fasilitas sekolah, kurikulum, dan metode mengajar pun menjadi stressor akademik (Desmita, 2014). Hal-hal lainnya yang mempengaruhi stres akademik, antara lain self-efficacy, kepribadian hardiness, optimisme, motivasi berprestasi, prokrastinasi, dan dukungan sosial orangtua (Yusuf \& Yusuf, 2020).
Di Indonesia, Siregar (2020) menemukan siswa kelas X SMA memiliki tingkat stres akademik yang tinggi. Studi lainnya juga menunjukkan sebanyak $81,6 \%$ siswa SMA kelas 10 dan 11 selama Pandemi COVID-19 termasuk ke dalam kategori stres akademik tinggi. Stres akademik tinggi diantara siswa SMA tersebut paling banyak dimiliki oleh siswa kelas 11 dan yang berusia 16 tahun (Gusella, 2020). Tingginya tingkat stres akademik yang dialami oleh siswa SMA turut dipengaruhi oleh fase perkembangan mereka yang berada di usia remaja.

Govaerst dan Gregoire (2004) menyatakan bahwa tekanan dan ekspektasi yang berhubungan dengan sekolah menjadi stressor harian yang sangat kuat bagi remaja. Remaja tergolong sangat rentan terhadap stres, yang mana mereka harus menghadapi tekanan untuk berhasil di kehidupan akademik dan juga harus menghadapi masa depan yang tidak pasti. Mereka juga harus menghadapi tuntutan lingkungan sosial, permasalahan emosional, fisik, dan keluarga. Tentunya, hal-hal tersebut berpengaruh pada kemampuan dan perfoma belajar mereka (Zarei dkk., 2016).

Saat seseorang mengalami stres, maka akan muncul reaksi dari stressor yang dialaminya tersebut. Yusuf (2011, dalam Azmy, Nurihsan, \& Yudha, 2017) membagi reaksi tersebut menjadi empat macam, yaitu (1) reaksi fisik seperti kelelahan, sulit tidur, sakit kepala, telapak tangan sering berkeringat; (2) reaksi emosional seperti merasa diabaikan, cemas, dan tidak memiliki kepuasan; (3) reaksi perilaku seperti sikap agresif, membolos, berbohong untuk menutupi kesalahan; dan (4) reaksi proses berpikir seperti sulit berkonsentrasi, perfeksionis, berpikir negatif dan tidak memiliki prioritas hidup.

Banyak sekali dampak negatif yang ditimbulkan oleh stres akademik bagi siswa. Liu (2017) menyatakan stres akademik secara konsisten menjadi faktor 
resiko paling kuat terhadap gejala gangguan depresi dan kecemasan pada remaja. Kecemasan dan stres yang berkaitan dengan performa di sekolah dapat memicu self-harm (Evans \& Hurrell, 2016). Self-harm memiliki arti yang lebih luas. Banyak sekali istilah yang digunakan, seperti parasuicide, non-suicidal selfinjury (NSSI), percobaan bunuh diri, deliberate self-harm (DSH), dll (Chandler, 2011).

Self-harm atau self-injury suatu perilaku yang dilakukan untuk mengatasi rasa sakit emosional dengan cara melukai diri sendiri. Perilaku ini dilakukan dengan sengaja tetapi tidak bertujuan untuk bunuh diri. Self-harm biasanya dilakukan sebagai bentuk pelampiasan dari emosi yang terlalu menyakitkan yang tidak bisa diungkapkan dengan kata-kata (Maidah, 2013). Dengan demikian, self-harm sering dijadikan sebagai coping stress yang salah.Bentuk-bentuk self-harm yang umumnya dilakukan menurut National Institute for Clinical Exellence (2011), antara lain a) memotong, membakar, menggigit; b) membenturkan atau memukul kepala; c) menggores anggota tubuh; d) menjambak dan mencabut rambut; e) overdosis; f) penyalahgunaan zat; g) perilaku berisiko; h) mengabaikan diri sendiri; dan i) gangguan pola makan.

Salah satu intervensi yang sering digunakan untuk mengatasi permasalahan stres dan kecemasan adalah mindfulness (Brausch, 2011). Mindfulness dijelaskan sebagai sebuah kondisi menghadirkan pikiran dengan penuh kesadaran pada keadaan atau momen saat ini (Creswell, 2017). Blackburn (2020) juga menjelaskan mindfulness sebagai kemampuan untuk secara penuh hadir pada kondisi saat ini, awas terhadap pikiran, tubuh, dan sekelilingnya, juga kemampuan untik menyaring hal-hal yang mengganggu yang dapat membuat tertekan. Proses ini sangat bertolak belakang dengan keadaan keseharian seseorang yang seringkali pikirannya berkelana atau memikirkan banyak hal, sehingga tidak berada dalam kondisi saat ini.

Praktik mindfulness telah berhasil meningkatkan kemampuan beradaptasi pada situasi menekan, kemampuan regulasi atensi, dan fokus (Blackburn, 2020). Mindfulness mendorong meningkatnya self-awareness dan perhatian terhadap situasi saat ini, yang dapat mengurangi stres dan kecemasan, sekaligus meningkatkan kesejahteraan psikologis (psychological well-being).

Menurut Baer dkk., (dalam Savitri \& Listiyandini, 2017) dimensi mindfulness terdiri dari tiga dimensi utama, yaitu: 1) Acting with awareness (bertindak dengan sadar) yang mana seseorang menyadari perilaku atau tindakan yang sedang dilakukannya dengan memunculkan kesadarannya saat ini (present moment); 2) Observasi yakni menyadari adanya stimulus internal seperti pikiran, perasaan, dan sensasi pada tubuh; 3) Accepting without judgement (menerima tanpa penilaian) yaitu menerima segala macam yang ada di pikiran, perasaan, tanpa memberikan penilaian.

Mindfulness memiliki beragam bentuk, seperti fokus pada sensasi yang dialami oleh tubuh (bernapas), reaksi emosi, mental images, mental talks, dan juga pengalaman perseptual (Kurt, Engelniederhammer, Sasse, \& Papastefanou, 2020). Salah satu bentuk mindfulness yang sering digunakan dalam berbagai macam intervensi psikologi adalah mindful breathing.

Mindful breathing dapat diartikan sebagai pernapasan secara sadar, mendalam, dan tenang. Seringkali proses bernapas tidak disadari, sehingga ketika mengalami stres maka individu cenderung bernapas dengan cara yang dangkal dan tegang yang membuat stres bertambah (Zhu dkk., 2017). Mindful breathing membuat individu menyadari proses bernapas mereka. Bernapas penting untuk pengaturan sistem saraf otonom dan fokus pada pernapasan telah terbukti meningkatkan self-awaresness serta 
pemfokusan pikiran (Idler, Mercer, Starosta, Bartfai, 2017). Praktik mindful breathing dapat diberikan kepada beragam kalangan, dari anak-anak, remaja, hingga dewasa. Pemberian intervensi mindful breathing pada setting pendidikan, termasuk dalam mengurangi kecemasan dan stres, juga menunjukkan hasil yang memuaskan (Brausch, 2011; Costello \& Lawler, 2014; Cho, Ryu, Noh, \& Lee, 2016; Blackburn, 2020).

Berdasarkan hal-hal yang telah dijabarkan, peneliti berkeinginan memberikan intervensi mindful breathing untuk mengatasi permasalahan stres akademik pada siswa Sekolah Menengah Atas (SMA). Adapun subjek dalam penelitian ini merupakan seorang remaja perempuan dengan status siswa SMA yang berusia 16 tahun, yang mengalami stres akademik dan melakukan self-harm sebagai coping stressnya.

\section{Metode}

Penelitian ini bertujuan untuk melihat keberhasilan intervensi mindful breathing untuk mengatasi stres akademik pada siswa SMA. Untuk mencapai tujuan tersebut, desain yang digunakan adalah desain penelitian kasus tunggal (singlesubject design), yaitu desain penelitian yang dilakukan pada satu orang subjek. Pada desain ini, peneliti fokus terhadap perilaku yang dimunculkan subjek sebelum intervensi diberikan dan setelah intervensi selesai dilakukan (Gravetter \& Forzano, 2009). Dengan demikian, peneliti akan melihat kondisi awal klien sebelum diberikan intervensi, yang disebut sebagai baseline. Setelahnya, peneliti akan melihat perilaku klien pasca diberikan intervensi. Baseline dijadikan dasar menentukan ada atau tidaknya perubahan perilaku. Melalui desain ini pun, peneliti dapat memeroleh hubungan sebab-akibat dari intervensi yang dilakukan.

Teknik pengambilan sampling dilakukan dengan cara purposive sampling, yaitu peneliti memilih sumber data penelitian yang dianggap dapat memberikan data yang dibutuhkan (Kumar, 1999). Adapun subjek penelitian merupakan seorang siswa kelas XI SMA dengan inisial $R$. $R$ berusia 16 tahun, berjenis kelamin perempuan, dan anak kedua dari tiga bersaudara. $\mathrm{R}$ bersekolah disalah satu SMA swasta di Bangka. $R$ menjadi subjek penelitian karena dianggap sesuai dengan kriteria penelitian, siswa SMA yang mengalami stres akademik dan melakukan self-harm.

Sebelum pelaksanaan intervensi, peneliti melakukan beberapa analisis kebutuhan terhadap $\mathrm{R}$ melalui pemeriksaan psikologis. Pemeriksaan dilakukan melalui wawancara terhadap $R$ dan kedua orangtuanya, serta pemberian tes psikologi berupa tes inteligensi IST dan tes grafis (DAP, BAUM, Wartegg). 


\begin{tabular}{|c|c|c|}
\hline $\begin{array}{l}\text { Eksternal } \\
\text { Keluarga } \\
\text { - } \quad \text { Tuntutan akademik yang tinggi } \\
\text { - } \quad \text { Corporal punishment dalam mendidik } \\
\text { - } \quad \text { Minim apresiasi } \\
\text { - } \quad \text { Pola asuh orangtua cenderung } \\
\text { otoriter } \\
\text { - } \quad \text { Orangtua membandingkan } \\
\text { pencapaian anak } \\
\text { Sekolah } \\
\text { - } \quad \text { Tuntutan akaemik yang tinggi } \\
\text { - } \quad \text { kungkungan pertemanan di sekolah } \\
\text { Teman mendukung } \\
\text { - } \quad \text { Memiliki teman online yang } \\
\text { - } \quad \text { Memportive } \\
\text { - } \quad \text { Pernah diabaikan dan ditinggalkan } \\
\text { teman saat SMP dan SMA }\end{array}$ & $\begin{array}{l}\text { Stres akademik } \\
\text { Self-harm } \\
\text { (cutting, mencubit } \\
\text { diri, tidak makan, } \\
\text { menjambak } \\
\text { rambut) }\end{array}$ & $\begin{array}{l}\text { Internal (Diri) } \\
\text { - } \quad \text { Kemampuan kognitif yang } \\
\text { - } \quad \text { memadai } \\
\text { - } \quad \text { Kelf-esteem cenderung rendah } \\
\text { - } \quad \text { Regulasi emosi yang belum baik } \\
\text { - } \quad \text { Kurang mendapat apresiasi } \\
\text { - } \quad \text { Kerhadap prestasi yang dicapai } \\
\text { - } \quad \text { melakukan hal yang diinginkan } \\
\text { - } \quad \text { cukup } \\
\text { Cenderung kurang mampu } \\
\text { menyesuaikan diri di lingkungan } \\
\text { yang tidak disukai }\end{array}$ \\
\hline
\end{tabular}

Gambar 1. Dinamika Permasalahan

Dari hasil pemeriksaan psikologis, dapat disimpulkan bahwa $\mathrm{R}$ mengalami kecemasan dan stres yang berkaitan dengan akademik. Sumber stres akademiknya berasal dari tuntutan orangtua yang menginginkan ia mendapatkan nilai yang baik. $R$ pun pernah mendapatkan hukuman fisik dari kedua orangtuanya apabila melakukan kesalahan dan mendapatkan nilai yang buruk. Hukuman tersebut didapatkannya sejak duduk di bangku Sekolah Dasar. Secara tidak sadar, $\mathrm{R}$ mengembangkan ketakutan mendapatkan hukuman apabila ia tidak berhasil mendapatkan nilai yang memuaskan seperti yang diharapkan orangtuanya.

Minimnya apresiasi orangtua terhadap pencapaian $R$, terutama di bidang akademik, membuat ia cenderung menjadi invidu yang kurang percaya diri. Terlebih lagi, ia sering dibandingbandingkan dengan kakaknya yang saat ini sedang berkuliah di luar negeri. $R$ pun menganggap dirinya tidak pintar dan tidak menjadi anak yang diinginkan oleh orangtuanya. la merasa rendah diri dan beranggapan tidak mampu melakukan apapun.

$$
\text { Pola asuh orangtua yang }
$$
cenderung otoriter, membuat $\mathrm{R}$ terbatas dalam menentukan hal-hal yang ingin ia lakukan. $\mathrm{R}$ cenderung ragu dan kurang mandiri ketika harus mengambil keputusan dalam hidupnya. Perasaan khawatir, takut gagal, dan keyakinan yang tergolong rendah akan kemampuannya mengerjakan tugas membuat ia mengalami tekanan saat mengerjakan tugas-tugas yang diberikan. Meskipun $\mathrm{R}$ memiliki kemampuan intelegensi yang memadai (skor IQ 106, skala Weschler), keyakinannya untuk berhasil dalam akademik cenderung kurang. la sebenarnya sudah cukup termotivasi untuk belajar, tetapi hal ini masih dipengaruhi oleh faktor eksternal.

Sekolah $\mathrm{R}$ termasuk sekolah swasta yang memiliki tuntutan akademik yang relatif tinggi. Pandemi Covid-19 membuat $R$ harus menjalani pembelajaran jarak jauh. Hal tersebut, semakin membuat $R$ kewalahan dan ditambah lagi ia harus mengerjakan tugas yang diberikan oleh

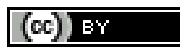

$\begin{array}{ll}\text { Review Date } & \text {; June 5, 2021 } \\ \text { Revised Date } & \text { : August 9, 2021 } \\ \text { Accepted Date } & \text { : September 12, 2021 }\end{array}$


guru. Meskipun guru-guru di sekolahnya tergolong baik dan peka terhadap kebutuhan siswa, $\mathrm{R}$ masih merasa butuh bantuan lebih. Ketika ia merasa tidak bisa mengerjakan tugas, ia cenderung ingin menyerah dan menyalahkan dirinya.

Saat di sekolah, $\mathrm{R}$ tidak banyak bergaul dengan teman-temannya. la hanya memiliki satu teman dekat yang dapat ia ajak untuk bertukar pikiran. Hubungan dengan teman-temannya dipersepsikan oleh $\mathrm{R}$ sebagai hubungan yang toxic. la tidak terlalu menyukai teman sekelasnya. la pernah mengalami kejadian yang tidak menyenangkan bersama teman sekelasnya, yang mana ia diabaikan oleh mereka. Hal ini juga membuat $R$ cenderung khawatir menjalin pertemanan yang dekat karena takut akan ditinggalkan.

Dapat dilihat, bahwa $\mathrm{R}$ belum memiliki support system yang baik yang dapat membantunya untuk mengatasi stres akademiknya. Terlebih lagi, ia masih belum mampu mengontrol emosi dan dirinya dengan baik. Ketidakmampuan $\mathrm{R}$ mengelola emosinya saat stres, cenderung membuat ia melampiaskan stresnya dalam bentuk melukai diri sendiri (self-harm).

Bentuk-bentuk self-harm yang pernah ia lakukan adalah cutting (memotong pergelangan tangan), mencubit tangan dan kaki, tidak makan, dan menjambak rambutnya. Keinginannya untuk melakukan self-harm muncul ketika ia tertekan karena merasa tidak mampu mengerjakan tugas. Gejala yang ia munculkan seperti menangis, panik, tremor, dan muncul beragam pikiran negatif, seperti "kamu akan gagal", dan "yaudah nggak usah dikerjain, nilai juga bakal jelek". R mengaku kesulitan untuk menghilangkan pikiran negatif yang muncul. la juga pernah melakukan hal-hal lain untuk mengurangi perilaku self-harm seperti, menangis, menggosokkan balsam/minyak angin di pergelangan tangan, mendengarkan musik, dan menonton. Akan tetapi, hal-hal tersebut tidak terlalu membantunya mengatasi stres dan tindakan self-harm.

Melihat kasus dan kebutuhan subjek, maka peneliti memberikan intervensi mindful breathing untuk mengatasi permasalahan stres akademik R. Intervensi dilakukan dengan tujuan membuat coping stress baru pada subjek agar tidak melakukan self-harm pada saat mengalami stres akademik. Intervensi ini juga bertujuan untuk mengurangi stres yang muncul pada saat mengerjakan tugas. Intervensi mindful breathing diberikan selama 2 minggu, dengan waktu 5 menit untuk tiap sesi. Sebelumnya, R mendapatkan sesi konseling sebanyak 5 kali dan sesi persiapan terlebih dahulu sebanyak satu sesi pertemuan. Pada sesi briefing, $\mathrm{R}$ diperkenalkan dengan metode mindfulness, bentuk-bentuk metode mindfulness yaitu mindful breathing, berlatih menggunakan teknik mindful breathing, dan evaluasi.

Metode mindful breathing yang digunakan merujuk pada UCLA Mindful Awareness Research Center (uclahealth. org, 2021). Tata cara melakukan mindful breathing dijabarkan sebagai berikut:

1. Klien berada dalam posisi rileks dan nyaman. Klien boleh dalam keadaan duduk, berdiri, ataupun berbaring. Boleh dalam keadaan mata terpejam atau terbuka. Posisi punggung harus tegak, tetapi tidak kaku. Tangan diistirahatkan dengan santai, lidah berada di langit-langit mulut atau pada posisi yang nyaman.

2. Klien diminta untuk menyadari dan mengajak tubuhnya untuk rileks. Klien diminta untuk merasakan sensasi yang ada pada tubuhnya dan membuat rileks area yang masih tegang.

3. Klien diminta untuk fokus pada napas dan menyadari ritme pernapasannya, tidak bernapas dengan panjang atau pendek tetapi bernapas secara alami. Klien diminta untuk menyadari area tubuhnya yang mendapatkan sensasi 
dari pernapasannya. Jika klien tidak bisa menyadarinya, tidak masalah.

4. Ketika pikiran klien mulai "berkelana", ajak klien untuk menyadari pikiran-pikiran tersebut dan fokus kembali pada pernapasannya.

5. Apabila klien mulai merasa "kosong" setelah beberapa lama bernapas, ajak untuk kembali lagi fokus pada pernapasannya.

6. Klien diminta untuk menyadari sensasi tubuhnya, seluruh tubuhnya, dan posisinya. Ajak klien untuk rileks dan selesai. Berikan apresiasi atas pencapaiannya.

Pada saat pelaksanaan intervensi, $R$ melakukan mindful breathing setiap hari, sebelum tidur. Mindful breathing dilakukan selama 5 menit di atas tempat tidur. Peneliti mengevaluasi hasil mindful breathing $\mathrm{R}$ setelah 1 minggu, dan perlakuan yang sama dilakukan untuk minggu kedua. Setelah 2 minggu, R akan bertemu dengan peneliti untuk evaluasi mengenai hasil mindful breathing yang telah dilakukan. Evaluasi berupa pengalaman saat melakukan mindful breathing (kesulitan atau hal-hal yang memudahkan) dan kondisi yang dirasakan setelah mindful breathing. Rancangan dan prosedur pelaksanaan intervensi dapat dilihat pada Tabel 1. 
Tabel 1.

Rancangan Intervensi dan Prosedur Pelaksanaan

\begin{tabular}{|c|c|c|c|c|}
\hline No & Sesi & Durasi & Tujuan & Kegiatan \\
\hline 1. & Konseling & 5 sesi & 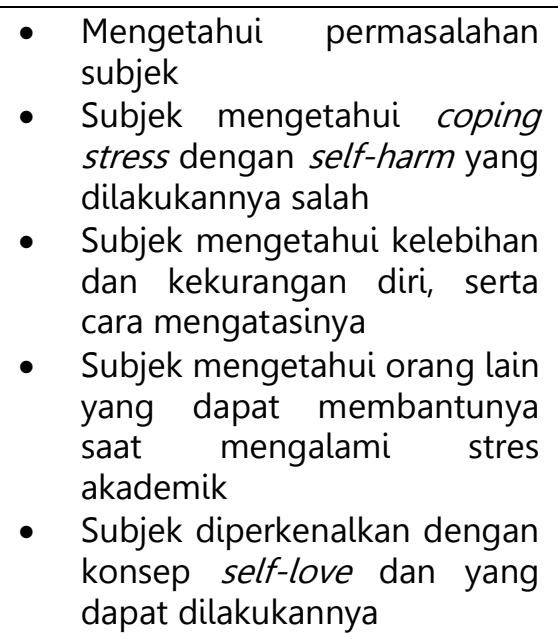 & $\begin{array}{l}\text { - Wawancara subjek R dan orangtua } \\
\mathrm{R} \\
\text { - } \quad \text { Pemberian asesmen psikologi } \\
\text { - } \text { Memberikan informasi mengenai } \\
\text { coping stressdan self-harm } \\
\text { - } \text { Identifikasi kelebihan dan } \\
\text { kekurangan diri } \\
\text { - } \quad \text { Identifikasi sumber dukungan } \\
\text { sosial } \\
\text { - Memberikan informasi mengenai } \\
\text { konsep self-love, mengisi self-love } \\
\text { checklist, dan cara melakukan self- } \\
\text { love }\end{array}$ \\
\hline 2. & Briefing & 1 hari & $\begin{array}{l}\text { - Subjek mengetahui intervensi } \\
\text { mindfulness dan mindful } \\
\text { breathing } \\
\text { - Subjek dapat melakukan } \\
\text { teknik mindful breathing }\end{array}$ & $\begin{array}{l}\text { - Memberikan informasi mengenai } \\
\text { intervensi mindfulness dan } \\
\text { mindful breathing } \\
\text { - Mengajarkan subjek R melakukan } \\
\text { teknik mindful breathing }\end{array}$ \\
\hline 3. & $\begin{array}{l}\text { Pelaksanaa } \\
\text { n\& } \\
\text { Evaluasi } \\
\text { Mingguan }\end{array}$ & 14 hari & $\begin{array}{l}\text { - Subjek melakukan teknik } \\
\text { mindful breathing sebelum } \\
\text { tidur }\end{array}$ & $\begin{array}{l}\text { - Subjek melakukan teknik mindful } \\
\text { breathing selama } 5 \text { menit sebelum } \\
\text { tidur } \\
\text { - Peneliti menanyakan efektivitas } \\
\text { mindful breathing setiap minggu }\end{array}$ \\
\hline 4. & $\begin{array}{l}\text { Evaluasi } \\
\text { Akhir }\end{array}$ & 1 hari & $\begin{array}{l}\text { - Subjek dan peneliti } \\
\text { mengetahui hasil teknik } \\
\text { mindful breathing terhadap } \\
\text { stres akademik }\end{array}$ & $\begin{array}{l}\text { - Subjek dan peneliti mengevaluasi } \\
\text { teknik mindful breathing pada sesi } \\
\text { tatap muka }\end{array}$ \\
\hline
\end{tabular}




\section{Hasil dan Pembahasan Sesi Konseling}

Sebelum dilakukannya intervensi mindful breathing, $\mathrm{R}$ mengikuti sesi konseling terlebih dahulu. Sesi ini bertujuan untuk masalah yang dihadapi, dan menginformasikan mengenai coping stressself-harm yang dilakukan $R$ pada saat tertekan atau stres adalah salah. $R$ juga diajak untuk mengetahui kelebihan dan kekurangan dirinya, serta cara memanfaatkan kelebihan yang ia miliki untuk mengatasi stres. la juga diajak untuk mencari tahu sumber dukungan dari orang-orang disekitarnya yang dapat membantunya pada saat stres muncul, seperti bercerita atau meminta saran. $\mathrm{R}$ pun diberikan pengetahuan mengenai self love dan cara melakukannya. $\mathrm{R}$ diberikan daftar berupa checklist mengenai hal-hal terkait self-love yang pernah ia lakukan dan apa saja yang perlu ia lakukan.

\section{Sesi Persiapan}

Pada sesi ini, $\mathrm{R}$ diperkenalkan dengan konsep mindfulness. Peneliti menjelaskan terlebih dahulu konsep mindfulness dan bentuk-bentuknya. Setelah $R$ mengetahui tentang mindfulness, $\mathrm{R}$ diajak untuk mencoba mindful breathing selama 1 menit. $\mathrm{R}$ diminta untuk melakukan pernapasan dalam dengan hitungan 4-7-8, yaitu menarik napas dalam dengan 4 hitungan, menahan napas selama 7 hitungan, dan menghembuskan napas melalui mulut selama 8 hitungan.

Pada saat latihan, $\mathrm{R}$ masih merasa sedikit terganggu dengan pikiranpikirannya. R diminta untuk fokus dan belajar menghilangkan pikiran-pikiran tersebut. Setelah $\mathrm{R}$ dirasakan telah lebih mampu melakukan mindful breathing, $\mathrm{R}$ ditanyakan kesan setelah melakukannya. Peneliti mengajak $\mathrm{R}$ untuk berkomitmen melakukan mindful breathing setiap hari sebelum tidur malam, dan R menyanggupi hal tersebut.

\section{Sesi Pelaksanaan}

Pelaksanaan intervensi dilakukan secara mandiri oleh $\mathrm{R}$ di rumahnya. $\mathrm{R}$ setiap malam melakukan mindful breathing selama 5 menit sebelum tidur malam. Selama minggu pertama, $\mathrm{R}$ berhasi melakukan mindful breathing sebanyak 5 kali. R tidak berhasil melakukan 2 sesi lainnya. Selama 1 minggu, R melaporkan bahwa pikiran negatif masih muncul saat ia melakukan mindful breathing. Ketika pikiran negatif tersebut muncul, $R$ mencoba melawannya dan berhasil. $R$ mengaku sempat merasa sedih akibat pikiran negatif tersebut, tetapi tidak terlalu parah seperti yang pernah ia rasakan sebelumnya.

Pada minggu kedua, $\mathrm{R}$ berhasil melakukan teknik mindful breathing dengan baik. la sudah merasa lebih tenang dan nyaman. Kemungkinan hal ini juga didukung dengan berkurangnya tugas yang diberikan pihak sekolah, sehingga ia memiliki waktu yang lebih banyak untuk beristirahat. Pikiran-pikiran negatif masih tetap muncul, tetapi R mengaku sudah lebih mampu mengontrolnya. Selama dua minggu melakukan teknik mindful breathing, $\mathrm{R}$ mengaku pikiran-pikiran negatif yang muncul sudah lebih berkurang, dan ia pun dapat tidur dengan lebih nyenyak.

\section{Sesi Evaluasi}

Sesi evaluasi dilakukan setelah satu minggu sesi pelaksanaan berakhir. $R$ bertemu dengan peneliti dan mengevaluasi hasil mindful breathing sebagai coping stress baru pada saat $R$ mengalami tekanan atau stres akademik. Berdasarkan laporan yang diberikan oleh $\mathrm{R}$, ia mengaku merasa lebih tenang dan nyaman. Meskipun banyak tugas dari sekolah, ia dapat mulai mengontrol pikiran negatif yang muncul dan tidak melakukan self-harm.

Sesi evaluasi juga digunakan untuk merefleksikan kondisi sebelum dan setelah melakukan mindful breathing. R mengaku sudah lebih mengenali pikiran

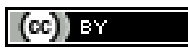


dan juga perasaan yang muncul pada saat ia mengalami stres akademik. la juga sudah bisa memberi "nama" dan "bentuk" kepada pikiran-pikiran negatifnya. Pada sesi ini, R pun diajak untuk lebih mengenal dan memahami potensi dirinya. la juga diarahkan untuk menentukan langkah selanjutnya, seperti memilih jurusan yang sesuai dengan minat dan bakatnya, serta melakukan hal-hal yang dapat membuat dirinya nyaman. 
Tabel 2.

Hasil Pelaksanaan Intervensi Mindful Breathing

\begin{tabular}{|c|c|c|c|}
\hline No & Sesi & Durasi & Hasil \\
\hline 1. & Persiapan & 1 hari & $\begin{array}{l}\text { - Subjek mengetahui konsep mindfulness dan mindful breathing } \\
\text { - Subjek berlatih mindful breathing dengan bantuan peneliti } \\
\text { - Subjek dapat melakukan mindful breathing tanpa bantuan peneliti }\end{array}$ \\
\hline 3. & $\begin{array}{l}\text { Pelaksanaan\& } \\
\text { Evaluasi } \\
\text { Mingguan }\end{array}$ & 14 hari & $\begin{array}{l}\text { - Pada minggu pertama, subjek melakukan mindful breathing sebelum } \\
\text { tidur selama } 5 \text { hari. Subjek gagal melakukan mindful breathing selama } \\
2 \text { hari. } \\
\text { - Subjek masih merasakan emosi dan pikiran negatif saat melakukan } \\
\text { mindful breathing, tetapi masih mampu ia hadapi } \\
\text { - Pada minggu kedua, subjek berhasil melakukan mindful breathing } \\
\text { sebelum tidur selama } 7 \text { hari. } \\
\text { - Subjek merasa lebih mampu mengontrol emosi dan pikiran negatif } \\
\text { yang muncul pada saat melakukan mindful breathing }\end{array}$ \\
\hline 4. & Evaluasi Akhir & 1 hari & $\begin{array}{l}\text { - Subjek merasa lebih mampu mengontrol emosi dan pikiran negatif } \\
\text { yang muncul } \\
\text { - Subjek dapat tidur lebih nyenyak } \\
\text { - Subjek sudah mampu mengidentifikasi emosi dan pikiran negatifnya } \\
\text { dan memberikan "nama" kepada pikiran-pikiran negatifnya } \\
\text { - Subjek tidak melakukan self-harm pada saat merasa tertekan } \\
\text { mengerjakan tugas } \\
\text { - Subjek mengetahui potensi yang ada pada dirinya dan membuat } \\
\text { rencana untuk studinya. }\end{array}$ \\
\hline
\end{tabular}


Tabel 3.

Perbandingan perilaku stres akademik dan self-harm

\begin{tabular}{|c|c|c|c|c|}
\hline Aspek & Indikator & Sebelum Intervensi & Minggu 1 Intervensi & $\begin{array}{c}\text { Minggu } 2 \\
\text { Intervensi }\end{array}$ \\
\hline & $\begin{array}{cl}\text { Reaksi Fisik: } \\
\text { - } & \text { Kelelahan } \\
\text { - } & \text { Sakit kepala } \\
\text { - } & \text { Sulit tidur } \\
\text { - } & \text { Telapak tangan } \\
& \text { berkeringat }\end{array}$ & $\begin{array}{ll}\text { - } & \text { Kelelahan } \\
\text { - } & \text { Sulit tidur dan } \\
& \text { sering begadang }\end{array}$ & $\begin{array}{ll}\text { - } & \text { Lebih tenang } \\
& \text { dan nyama } \\
\text { - } & \text { Tidur lebih } \\
& \text { nyenyak }\end{array}$ & 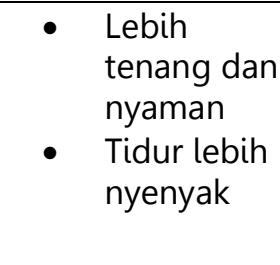 \\
\hline & $\begin{aligned} & \text { Reaksi Emosional: } \\
& \text { - } \text { Merasa diabaikan } \\
& \text { - } \text { Cemas } \\
& \text { - } \text { Tidak memiliki } \\
& \text { kepuasan }\end{aligned}$ & $\begin{array}{l}\text { Merasa sedih dan } \\
\text { menangis }\end{array}$ & Masih merasa sedih & $\begin{array}{l}\text { Tidak merasa } \\
\text { sedih }\end{array}$ \\
\hline \multirow[t]{2}{*}{$\begin{array}{c}\text { Stres } \\
\text { Akademik }\end{array}$} & $\begin{aligned} & \text { Reaksi Perilaku: } \\
& \text { - } \text { Sikap agresif } \\
& \text { - } \text { Membolos } \\
& \text { - } \text { Berbohong }\end{aligned}$ & - & - & - \\
\hline & $\begin{array}{cl}\text { Reaksi Proses Berpikir: } \\
\text { - } \\
\text { - } & \text { Pulit berfeksionsentrasi } \\
\text { - } & \text { Berpikir negatif } \\
\text { - } & \text { Tidak memiliki } \\
& \text { prioritas hidup }\end{array}$ & $\begin{array}{l}\text { Berpikiran negatif dan } \\
\text { tidak mampu } \\
\text { melawannya }\end{array}$ & $\begin{array}{l}\text { Pikiran negatif masih } \\
\text { muncul tetapi } \\
\text { berhasil dilawan }\end{array}$ & $\begin{array}{l}\text { Pikiran negatif } \\
\text { masih muncul } \\
\text { dan sudah lebih } \\
\text { mampu } \\
\text { melawannya }\end{array}$ \\
\hline Self-harm & $\begin{array}{ll}\text { - } & \text { Memotong, } \\
& \text { membakar, } \\
& \text { mengigit tubuh } \\
\text { - } & \text { Membenturkan atau } \\
\text { memukul kepala } \\
\text { - } & \text { Menggores anggota } \\
& \text { tubuh } \\
\text { - } & \text { Menjambak dan } \\
\text { - } & \text { Ovencabut rambut } \\
\text { - } & \text { Penyalahgunaan zat } \\
\text { - } & \text { Perilaku berisiko } \\
\text { - } & \text { Mengabaikan diri } \\
\text { - Gangguan pola } \\
& \text { makan } \\
\end{array}$ & $\begin{array}{ll}\text { - } & \text { Memotong } \\
\text { pergelangan } \\
\text { tangan } \\
\text { - } & \text { Menjambak } \\
& \text { rambut } \\
\text { - } & \text { Gangguan pola } \\
& \text { makan (tidak } \\
& \text { makan) } \\
\text { - } & \text { Mencubit diri }\end{array}$ & $\begin{array}{l}\text { Tidak ada perilaku } \\
\text { self-harm }\end{array}$ & $\begin{array}{l}\text { Tidak ada } \\
\text { perilaku self- } \\
\text { harm }\end{array}$ \\
\hline
\end{tabular}




\section{Diskusi Hasil}

Secara umum, pemberian intervensi kepada subjek merupakan salah satu bentuk belajar.Menurut Kingsley (dalam Hamzah, 2012), belajar merupakan proses yang mana sebuah perilaku (dalam arti luas) diubah melalui praktik atau latihan. Menurut Bloom dan Wohl (dalam Hamzah, 2012), belajar membawa perubahan pada tiga aspek, yakni kognitif, afektif, dan psikomotorik. Begitupula dengan $\mathrm{R}$ yang mendapatkan intervensi mindful breathing, yang mana ia mengalami perubahan pada saat sebelum dan setelah melakukan intervensi.

Pada aspek kognitif, $R$ awalnya tidak mengetahui bahwa self-harm yang ia lakukan saat tertekan mengerjakan tugas adalah coping stres yang salah. la juga tidak mengetahui penyebab perilaku selfharm yang ia lakukan. $\mathrm{R}$ masih belum mampu untuk mengidentifikasi emosi dan pikiran negatif yang muncul, terutama pada saat mengerjakan tugas. la juga masih belum mengetahui coping stress dengan cara mindful breathing. Setelah diberikan intervensi, $R$ mengetahui bahwa self-harm bukan coping stress yang tepat untuk mengatasi permasalahan stres akademiknya. la sudah mampu mengidentifikasi emosi dan pikiran negatif yang muncul, terutama pada saat mengerjakan tugas. Selain itu, $R$ juga mengetahui coping stress dalam bentuk mindful breathing yang dapat dilakukannya pada saat mengalami stres akademik.

Pada aspek afektif, $R$ sebelumnya tidak menyadari apa saja hal-hal yang selama ini membuatnya mengalami stres akademik. la juga belum mampu menilai emosi dan pikiran yang baik untuk dirinya dan tidak baik untuk dirinya. Setelah diberikannya intervensi, $R$ sudah mulai menyadari penyebab ia mengalami stres akademik. la juga sudah mulai menyadari hal-hal positif apa saja yang ia miliki dan cara untuk mengembangkannya. Selain itu, $\mathrm{R}$ sudah lebih mampu menilai mana emosi dan pikiran yang baik dan tidak baik untuk dirinya. Ketika emosi dan pikiran tersebut cenderung negatif, $R$ sudah mampu menyadari dan memikirkan halhal yang perlu ia lakukan untuk mengatasinya.

Selanjutnya, pada aspek psikomotor, awalnya $\mathrm{R}$ belum bisa melakukan teknik coping stress dengan mindful breathing. Setelah diberikan pengajaran pada sesi briefing, $\mathrm{R}$ sudah bisa melakukannya. Bahkan, $\mathrm{R}$ sudah berhasil melakukannya sendiri selama 2 minggu tanpa bantuan dari peneliti. Ia juga yang pada mulanya belum mampu mengatasi emosi dan pikiran negatifnya, menjadi lebih mampu mengelola emosi dan pikiran negatifnya tersebut.

Berdasarkan hal-hal yang telah dilakukan, intervensi mindful breathing untuk mengatasi permasalahan stres akademik pada $\mathrm{R}$ dapat dikatakan berhasil. Hal ini tentunya sejalan dengan yang disampaikan oleh Castello dan Lawler (2014). Penelitian tersebut menjelaskan bahwa mindfulness yang dilakukan dalam bentuk mindfulbreathing memberikan hasil positif mengurangi persepsi mengenai stres pada siswa. Dengan melakukan mindful breathing, sebagaian besar siswa melaporkan mereka lebih peka terhadap tubuh mereka, lebih mampu fokus terutama ketika banyaknya pikiran negatif yang muncul, bahkan meningkatkan kemampuan regulasi diri (Castello \& Lawler, 2014). Arch dan Kraske (2006), sebelumnya juga menyebutkan bahwa individu yang melakukan praktik mindful breathing memang lebih baik dalam meregulasi emosinya.

Kedua hasil penelitian tersebut, selaras dengan yang disampaikan oleh $R$ mengenai proses dan hasil mindful breathing yang dilakukannya. la menjadi lebih mampu mengenali dan mengontrol emosi dan pikiran negatif yang muncul. Regulasi dirinya juga semakin baik yang ditunjukkan dengan tidak melakukan self- 
harm pada saat tertekan mengerjakan tugas sekolah.

Munculnya kemampuan regulasi diri dan emosi pada $\mathrm{R}$, merupakan salah satu dampak positif mindful breathing. Seperti yang diungkapkan oleh Cho dkk., (2016), selama proses mindful breathing individu tidak hanya menyadari pikiran negatif mereka saja. Individu juga menyadari adanya pikiran netral yang dapat membantu mereka mendapatkan perspektif tentang pengalaman mereka melalui metakognisi. Dengan demikian, pengalaman ini tentunya membantu $R$ mengembangkan pikiran netral pada saat mengalami tekanan atau situasi yang tidak menyenangkan.

Keberhasilan intervensi mindful breathing untuk mengatasi stres akademik juga disebabkan oleh teknik bernapas yang menjadi kunci utama dari intervensi ini. Bernapas memiliki keterkaitan erat dengan emosi yang dimunculkan individu. Philippot, Chapelle, dan Blairy (2010) menyebutkan, beragam emosi berasosiasi dengan berbagai bentuk pernapasan. Mengubah cara bernapas juga akan mengubah perasaan. Pada saat senang, individu akan bernapas secara teratur, dalam, dan pelan. Sebaliknya, ketika cemas atau marah, maka pernapasan menjadi tidak teratur, pendek, cepat, dan dangkal.

Lebih lanjut, Seppälä, Bradley, dan Goldstein (2020) menjelaskan, dengan mengubah ritme napas menandakan adanya relaksasi. Hal ini memperlambat detak jantung dan menstimulasi saraf vagus,yang membentang dari batang otak ke perut, dan merupakan bagian dari sistem saraf parasimpatis yang bertanggung jawab untuk "istirahat dan mencerna" tubuh.Terpicunya saraf parasimpatis pada saat melakukan teknik mindful breathing, membuat $\mathrm{R}$ menjadi merasa lebih nyaman dan tenang. Mindful breathing yang dilakukan $R$ setiap hari sebelum tidur, memberikan sebuah kebiasaan yang positif untuk subjek, sehingga memberikan hasil yang lebih memuaskan.

Keberhasilan pelaksanaan intervensi juga didukung dengan sikap $R$ yang kooperatif. Mindfulness merupakan sebuah konsep yang harus dilakukan atas kesediaan individu. Hal ini dikarenakan, menurut Baer dkk., (dalam Savitri \& Listiyandini, 2017) dimensi mindfulness terdiri dari acting with awareness (bertindak dengan sadar), observasi diri, dan accepting without judgement (menerima tanpa penilaian). Maka, pelaksanaan mindfulness harus berdasarkan partisipasi aktif dari individu itu sendiri. Pada saat pelaksanaan, individu harus secara aktif menyadari hal-hal yang terjadi pada tubuh, perasaan, dan pikiran, juga menerimanya tanpa syarat. Tanpa adanya sikap kooperatif dari $R$, tentunya proses intervensi tidak akan bisa berjalan dengan baik. Selain itu, $R$ juga memiliki motivasi untuk berubah yang turut membantu dalam keberhasilan intervensi.

Kemudian, secara kognitif pun $\mathrm{R}$ tidak memiliki hambatan yang membuatnya kesulitan menerima informasi yang diberikan. Hal ini tentunya berkontribusi pada saat sesi persiapandan pelaksanaan intervensi. $\mathrm{R}$ dapat dengan mudah memahami konsep mindfulness yang dijelaskan oleh peneliti, dapat mengikuti instruksi dengan baik, dan melaksanakan mindful breathing secara mandiri. Dengan kemampuan kognitif yang memadai pula, $\mathrm{R}$ dapat mengidentifikasi permasalahan yang dihadapi, pikiran, dan emosi negatif yang dimilikinya, serta mampu mengelolanya dengan baik.

Hal yang perlu didiskusikan selanjutnya, sebelum diberikan intervensi mindful breathing, $\mathrm{R}$ juga telah diberikan konseling. Kegiatan konseling yang diberikan berupa identifikasi masalah, pengenalan diri (kelebihan dan kekurangan), my supporter, dan self-love check. Kegiatan konseling tersebut memberikan gambaran kepada $R$ mengenai hal-hal yang terjadi pada 
dirinya, kelebihan diri yang dapat ia kembangkan, mengidentifikasi sumber dukungan sosial yang dapat membantunya menghadapi stres akademik, dan kegiatan self-love apa saja yang telah dan perlu ia lakukan. Sesi konseling yang dilakukan $\mathrm{R}$ dapat dikatakan memberikan kontribusi yang positif bagi keberhasilannya mengatasi stres akademik. Dengan demikian, pelaksanaan sesi konseling sebelum pemberian intervensi, juga turut menjadi faktor eksternal yang mendukung keberhasilan intervensi mindful breathing untuk mengatasi stres akademik.

Meskipun intervensi menunjukkan hasil yang memuaskan dalam mengatasi stres akademik, akan tetapi ada hal-hal lain yang perlu untuk diperhatikan. Pertama, pada saat pelaksanaan intervensi berlangsung di minggu kedua, $R$ melaporkan ia tidak mendapatkan tugas sekolah yang banyak. Tentunya kondisi ini berbeda ketika banyaknya tugas yang menjadi pemicu stres akademiknya. Di minggu kedua, $\mathrm{R}$ memiliki waktu yang lebih banyak untuk bersantai, sehingga hal ini turut membuat ia merasa lebih rileks dan tenang.

Kedua, sebelum diberikan konseling dan intervensi, $\mathrm{R}$ mengaku memiliki waktu tidur yang tidak menentu. la bisa begadang mengerjakan tugas semalaman, sehingga waktu tidurnya pun berkurang. Kurang tidur pun menjadi salah satu pemicu masalah kesehatan psikologis, termasuk stres (Lemma, Gelaye, Berhane, Worku \& Williams, 2012). Melihat hal tersebut, peneliti meminta $\mathrm{R}$ untuk mengubah waktu tidurnya menjadi lebih teratur pada saat pelaksanaan intervensi. $R$ melaporkan selama sesi pelaksanaan, ia tidur antara pukul 22:00-23:00 WIB. Adanya perubahan pola tidur $\mathrm{R}$ menjadi lebih teratur, turut membantu mengurangi gejala stres akademik yang dihadapinya.

\section{Kesimpulan}

Penelitian ini dilakukan untuk mengetahui keberhasilan intervensi mindful breathing dalam mengatasi stres akademik pada siswa SMA. Berdasarkan hasil penelitian, peneliti menyimpulkan bahwa intervensi mindful breathing berhasil mengatasi stres akademik pada siswa SMA. Hal ini terlihat dari perubahan yang terjadi secara kognitif, afektif, dan psikomotrik. Perubahan pun terlihat dari tidak adanya perilaku self-harm pada saat dan setelah diberikan intervensi, karena munculnya regulasi diri pada subjek. Subjek juga merasa lebih nyaman dan tenang, serta mampu mengontrol pikiran dan emosi negatif saat berada dalam situasi yang menekan.

Meskipun demikian, masih terdapat beberapa keterbatasan dalam penelitian ini, terutama dalam teknis pelaksaan intervensi. Oleh karena itu, akan diberikan beberapa saran yang dapat dipertimbangkan bagi penelitian serupa. Dalam pelaksanaan intervensi, tidak ada pengukuran tingkat stres akademik yang dialami oleh subjek. Hal ini tentunya membuat tidak adanya gambaran awal atau data baseline untuk melihat perubahan sebelum dan setelah diberikan intervensi.

Hasil penelitian hanya berdasarkan data kualitatif, sehingga akan lebih baik jika didukung dengan data kuantitatif. Selanjutnya, akan lebih baik jika pada pelaksanaan intervensisubjek menulis jurnal untuk mencatat pikiran, perasaan, dan perilaku saat melakukan mindful breathing. Hal ini berguna untuk melihat dinamika yang terjadi pada subjek ketika melakukan mindful breathing. Harapannya, catatan tersebut dapat membantu subjek untuk melihat perubahan yang terjadi pada dirinya, sekaligus menjadi data kualitatif bagi penelitian. 


\section{Daftar Pustaka}

Arch, J.J., \& Craske, M.G. (2006). Mechanism of mindfulness: Emotion regulation following a focused breathing induction. Behaviour Research and Therapy, 44(12), 18491858

Azmy, A.N., Nurihsan, A.J., \& Yudha, E.S. (2017). Deskripsi gejala stres akademik dan kecenderungan pilihan strategi koping pada siswa berbakat. Indonesian Journal of Educational Counseling, 1(2), 197-208

Blackburn, T. (2020). The relationship between mindfulness, academic stress, and attention. Tesis. Utah State University

Brausch, B.D. (2011). The role of mindfulness in academic stress, selfefficacy, and achievement in college students. Tesis. Eastern Illinois University

Cho, H., Ryu, S., Noh, J., \& Lee, J. (2016). The effectiveness of daily mindful breathing practices on test anxiety of students. PLos One, 11(1), 1-10

Costello, E., \& Lawler, M. (2014). An exploratory study of the effects of mindfulness on perceived levels of stress among school-children from lower economic backgrounds. The International Journal of Emotional Education, 6(2), 21-39

Creswell, J.D. (2017). Mindfulness interventions. The Annual Review Psychology, 68(18), 1-26.

Desmita. (2014). Psikologi perkembangan. Bandung: PT Remaja Rosdakarya

Evans, R., \& Hurell, C. (2016). The role of schools in children and young people's self-harm and suicide: Systematic review and meta-ethnography of qualitative research. BMC Public Health, 16, 1-16

Govarest, S., \& Gregoire, J. (2004). Stressfull academic situations: Study on appraisal variables in adolescence. British Journal of Clinical Psychology, 54, 261-271

Gravetter, F.J., \& Forzano, L.B. (2009). Research methods for behavioral sciences ( $3^{\text {rd }} E d$.). Belmont, CA: Wadsworth

Gusella, M. (2020). Gambaran stres akademis siswa sma selama pandemi covid-19. Skripsi. Fakultas Pendidikan Psikologi Universitas Negeri Jakarta

Hamzah, S.H. (2012). Aspek pengembangan peserta didik: Kognitif, afektif, psikomotorik. Dinamika Ilmu Jurnal Pendidikan, 12(1), 1-12

Idler, A.M., Mercer S.H., Starosta, L., \& Bartfai, J.M. (2017). Effects of a mindful breathing exercise during reading fluency intervention for students with attentional difficulties. Contemporary School Psychology, 21(4), 323-334

Kumar, R. (2005). Research methodology: A step-by-step guide for beginners (2nd $E d$.). London: Sage

Kurt, L., Engelniederhammer, A., Sasse, H., \& Papastefanou, G. (2020). Effect of a short mindful-breathing intervention on the psychophysiological stress reactions of german elementary school children. School Psychology International, 41(3), 218-238

Lemma, S., Gelaye, B., Berhane, Y., Worku, A., \& Williams, M. A. (2012). Sleep quality and its psychological correlates among university students in Ethiopia : A cross sectional study. $B M C$ Psychiatry, 12(237), 1-7. 
Liu, F. (2017). Academic stres and mental health amoing adolescents in shenzhen, china. Tesis. Faculty of Health Queensland University of Technology

Maidah, D. (2013). Self-injury pada mahasiswa (Studi kasus pada mahasiswa pelaku self-injury). Developmental and Clinical Psychology, 2(1), 6-13

National Institute for Clinical Excellence. (2011). Self-harm: Longer-term management (CG 133). London: The British Psychological Society and The Royal College ofPsychiatrists

Philippot, P., Chapelle, G., \& Blairy, S. (2010). Respiratory feedback in the generation of emotion. Cognition and Emotion, 16(5), 605-627. DOI: 10.1080/02699930143000392

Reddy, K.J., Menon, K., \& Thattil, A. (2018). Academic stress and its sources among university students. Biomedical \& Pharmacology Journal, 11(1), 531-537

Savitri, W.C., \& Listiyandini, R.A. (2017). Mindfulness dan kesejahteraan psikologis pada remaja. Psikohumaniora: Jurnal Penelitian Psikologi, 2(1), 43-59

Seppälä, E., Bradley, C., \& Goldstein, M.R. (2020, 29 September). Research: Why breathing is so effective at reducing stress. Harvard Business Review. Diakses dari https://hbr.org/2020/09/researchwhy-breathing-is-so-effective-atreducing-stress\#

Siregar, A.M.L. (2020). Gambaran stres akademik siswa kelas x SMA Negeri 1 tebing tinggi. Skripsi. Fakultas Psikologi Universitas Sumatera Utara

Undang-Undang Nomor 20 tahun 2003 tentang Sistem Pendidikan Nasional
Yusuf, N.M., \& Yusuf, J.M. (2020). Faktorfaktor yang mempengaruhi stres akademik. Psyche 165 Journal, 13(2), 235-239

Zarei, P., Hashemi, T., Sadipoor, S., Delavar, A., \& Khoshnevisan, Z. (2016). Effectiveness of coping strategies in reducing student's academic stress. International Journal of Mental Health and Addiction, 14(6), 1057-1061

Zhu, B., Hedman, A., Feng, S., Li, H., \& Osika, W. (2017). Designing, prototyping and evaluating digital mindfulness applications: A case study of mindful breathing for stress reduction. Journal of Medical Internet Research, 19(6) 